\title{
The Paradoxes of Decent Work in Context: A Cultural Political Economy Perspective ${ }^{1}$
}

\author{
Felix Hauf, Goethe University Frankfurt, Germany
}

\begin{abstract}
Scientific discourses of decent work can be roughly grouped into two main lines of interpretation. The first, optimistic line sees the International Labour Organisation's (ILO) decent work agenda as indicative of counter-hegemonic forces successfully injecting post-neo-liberal norms into global labour regulation. Specifically, feminist scholars have welcomed the emergence of decent work, because of its explicit concern with non-standard work, informal labour and care work. The second, more pessimistic line is critical of the decent work agenda, seeing it as compatible with or even reinforcing neo-liberal hegemony, especially because of its embrace of soft labour regulation and corporate social responsibility. This article aims to analyse the paradoxes of decent work by putting this discourse in its historical and theoretical context. The article first draws on the framework of Cultural Political Economy (CPE) to identify competing 'economic imaginaries' of decent work. Two prominent interpretations will be juxtaposed to outline a 'feminist' and a 'business case' decent work imaginary. Second, the article interrogates two different ILO initiatives, each of which is underpinned by one of these decent work imaginaries, in terms of the ways they may challenge or reinforce neo-liberal hegemony - the Domestic Workers Convention and the Better Work Programme.
\end{abstract}

\section{KEYWORDS}

Decent work, economic imaginary, cultural political economy, domestic workers convention, better work programme

\section{Introduction}

In 1999, the International Labour Organisation (ILO) adopted 'decent work' as the new overarching discourse organising its activities in the age of globalisation. This discourse is the result of a major revision process within the ILO and it is seen as a response to the challenges of neoliberal globalisation in order to strengthen its social dimension (Sengenberger, 2001). Scientific discourses of decent work can be roughly grouped into two main lines of interpretation. The first, optimistic line sees the ILO's decent work agenda as indicative of counter-hegemonic forces successfully injecting post-neo-liberal norms into global labour regulation. Specifically, feminist scholars have welcomed the emergence of decent work, because of its explicit concern with nonstandard work, informal labour and unpaid reproductive work. The second, more pessimistic line is critical of the decent work agenda, seeing it as compatible with or even reinforcing neo-liberal hegemony, especially because of its embrace of soft labour regulation and corporate social responsibility. This article aims to analyse the paradoxes of decent work by taking a closer look at the optimistic and the pessimistic decent work imaginaries. Drawing on the theoretical framework of 
Cultural Political Economy (CPE), the article first analyses the emergence of decent work in historical context and identifies competing 'economic imaginaries' of decent work. ${ }^{2}$ Two prominent interpretations will be juxtaposed to outline a 'feminist' and a 'business case' decent work imaginary. Second, the article interrogates two different ILO initiatives, each of which is underpinned by one of these decent work imaginaries, in terms of the ways they may challenge or reinforce neo-liberal hegemony - the Domestic Workers Convention and the Better Work Programme.

\section{Competing Decent Work Imaginaries}

Scientific discourses on decent work can be clustered around a basic tension between optimistic and pessimistic views regarding its progressive potential. The following juxtaposition does not represent a full review of the available literature. Rather, two prominent positions are examined in order to tease out the paradoxes of decent work.

An example of the optimistic view is Leah Vosko's (2002) feminist perspective on decent work. Revisiting Robert Cox's (1977) essay Labor and Hegemony, she agrees with him that the ILO was implicated in maintaining hegemonic power relations until the end of the Cold War. Cox (1977: 389) had argued that a certain form of corporatism had been institutionalised in the ILO's tripartite structure, locking in 'a form of productive relations, one based on an ideology of non-antagonistic relations and on bureaucratized structures of representation and control'. This form of corporatism, however, was typical for the Fordist mode of regulation, which was based on national class compromises between capital and labour mediated by national welfare states. Corporatist trade unions privileged the Fordist 'standard employment relationship' - formal, full-time, permanent employment with relatively high wages often reserved for white middle-class 'male breadwinners' (Pfau-Effinger, 2004) - and abandoned both informal, marginalised workers (often female and migrant) within the centre and workers in the periphery. In contrast to the hegemonic function the ILO fulfilled during the Cold War, Vosko (2002: 20) argues that the emergence of the decent work discourse in the era of globalisation reveals 'a growing counter-hegemonic presence inside the ILO and especially at its margins, where transnational coalitions between organized labour, emerging labour organizations in the informal sector and NGOs are growing'. For her, decent work is underpinned by two rather different, if not contradictory pillars. The first is the ILO's focus on core labour standards, a minimum set of conventions codifying universal labour rights every member state must ratify (freedom of association, prohibition of child labour, prohibition of forced labour and prohibition of discrimination) as specified in the Declaration on Fundamental Principles and Rights at Work (ILO, 1998). The core labour standards have been criticised from a feminist vantage point for encouraging a 'basically voluntarist approach to labour regulation, severing ILO conventions from their principle mechanism of implementation (ratification into domestic law), and endorsing business "self-regulation" through things like voluntary codes of conduct' (Elias, 2007: 47). These 'soft law' tendencies reveal that the core labour standards approach works within and to the benefit of what Elias calls the 'neoliberal development paradigm' (Elias, 2007: 51).

The core labour standards, however, are only one of the pillars of the decent work agenda. The second pillar, according to Vosko (2002: 20), is the ILO's new commitment to extending existing labour rights and social standards to marginalised groups of workers who have previously been excluded from these rights as exemplified by the Convention Concerning Home Work (ILO, 1996). Taking the latter as an example, Vosko concludes that instruments aimed to improve working conditions and labour rights of marginalised workers represent a victory for counter-hegemonic forces within the ILO, but they lack force. Although she acknowledges that this victory may be largely symbolic in nature (Vosko, 2002: 33), she agrees with Prugl (1999) that it is pivotal for the 
global feminist movement, because the ILO for the first time has moved beyond the male standard employee of Fordism and addresses the needs of mostly female informal and marginalised workers, especially in and from the Global South. Therefore, while the first pillar of decent work potentially has the negative effect of reinforcing hegemonic power relations within the ILO, the second pillar, according to Vosko (2002), reveals the counter-hegemonic potential of the decent work discourse if appropriated by progressive trade unions, women's groups and other non-governmental organisations (NGOs). The CPE view adopted here, however, directs attention to the question of whether - and if so, how - the symbolic victory of the feminist movement on paper, on the level of what can be called a 'discursive economy of representation' (Chowdhry, 2004: 233), translates into actual improvements of working conditions of women workers on the ground, in the material economy of exploitation, or whether it runs the risk of getting tangled up in what Elias (2007: 50) calls a 'hegemonic politics of co-option'. In other words, does the decent work agenda's new concern with the informal sector provide the material basis for moving beyond the neo-liberal development paradigm? Or does it merely accommodate feminist claims discursively without providing the material means to challenge the structures of neo-liberal capitalism, thereby actually serving to reinforce neo-liberal hegemony?

Guy Standing (2008) certainly believes in the latter. He represents the pessimistic view of decent work. He laments that decent work has marginalised the traditional ILO regime of industrial relations and adversarial bargaining, and interprets its emergence as a sign of organised labour's defeat by neo-liberal hegemony. The Convention Concerning Home Work is a good example for contrasting the optimistic with the pessimistic view of decent work. Standing (2008: 366), although agreeing that the convention represents an attempt to extend labour rights to marginalised workers and that the ILO's new concern with labour relations beyond the male standard employment relationship of Fordism is to be welcomed, calls it 'a dead letter', looking at the lack of ratifications rather than the standard-setting process itself. Standing, a former ILO official with an insider's view, discusses the role of the ILO in the era of globalisation in historical context. He argues that, while the ILO had an important role in the Keynesian regulation of national labour markets during Fordism, it has recently struggled to retain this role, because neo-liberal globalisation has undermined its foundations. The ILO failed to adequately respond to the neo-liberal imaginary of 'supply-side economics', which originated from the economics departments of the Universities of Chicago and Columbia and was quickly taken up by powerful international organisations such as the International Monetary Fund (IMF) and the World Bank. Instead of confronting the structural adjustment programmes of these organisations, shock therapy policies in the former Soviet Union, and their disastrous effects on labour and social policies worldwide, 'the ILO did not respond' (Standing, 2008: 363), resulting in a loss of credibility and voice. The subsequent proliferation of neo-liberal policies geared towards the flexibilisation of labour markets further gave rise to the phenomena typical of the neo-liberal world of work (feminisation, casualisation, informalisation, outsourcing, sub-contracting, etc.), further undermining the regulating function of the ILO. After a failed attempt to counter this development with a Convention on Contract Labour, the ILO resorted to restructuring itself under the Christian Democrat Director-General Michel Hansenne, resulting in the 1998 Declaration limiting the body of the international labour code to the above-mentioned core labour standards. For Standing, this represents a major setback:

The four core standards enshrined in the Declaration are 'negative rights' that lie outside the sphere of social or work rights. Banning 'the worst forms of child labour', banning 'forced labour', campaigning against gender discrimination and defending freedom of association are matters of common and civil law. They do not constitute a strategy or a progressive agenda (Standing, 2008: 367). 
The 1998 Declaration further weakened the ILO, because it envisages only promotional measures to improve implementation of core standards, rather than the possibility of sanctions: 'Soft law was replacing binding law' (Standing, 2008: 367). Standing (2008: 368) links this development to the ILO's endorsement of emerging forms of private self-regulation such as voluntary codes of conduct and corporate social responsibility (CSR), representing 'a further way by which the traditional ILO regime has been marginalized'. The more recent emergence of decent work as the overarching theme of the ILO under Director-General Juan Somavia is seen in a similar vein. Standing (2008: 370) criticises decent work as a 'slogan' and a 'mantra' leaving 'too much room for flabby platitudes' due to its inherent vagueness. The language of 'social dialogue', central to the decent work discourse, replaced traditional understandings of industrial relations and collective bargaining, resulting in a "non-confrontational mode that sidelines equality while espousing the vagueness of "decency", "fairness" and "dialogue" (Standing, 2008: 371). In this perspective, decent work is largely an ethical rhetoric that masks the fact that the ILO lacks the power to substantially challenge hegemonic power relations in the era of neo-liberal globalisation.

In CPE terms, these different views can be conceptualised as competing decent work imaginaries - a feminist imaginary stressing its progressive potential for regulating the informal economy, and a business case imaginary foregrounding CSR and business self-regulation. The CPE perspective helps to understand the vagueness of the decent work agenda, which symbolically proclaims the right to decent work for all without providing substantial language as to what decent work means in the concrete and how it may be achieved practically. It is exactly this vagueness, the big gap between the global discourse and the wide range of (trans-) local practices it may be used to justify, that makes decent work an 'economic imaginary' (Sum and Jessop, 2013: 182) par excellence. Initially, its discursive or semiotic dimension was more important in order to gather support from different actors. The symbolic right to decent work for all workers made it an attractive concept for trade unions, women's organisations and other NGOs, while the emphasis on employment creation and competitiveness allowed for employers and states to endorse the concept. The vagueness of the discourse allows for all stakeholders to subscribe to their own decent work imaginary, while leaving open the question of which practical routes are to be taken towards the realisation of decent work.

\section{Cultural Political Economy}

A CPE perspective on decent work examines its discursive (or 'semiotic') dimensions in relation to its material (or 'structural') dimensions. The emerging paradigm of CPE as put forward by Bob Jessop, Ngai-Ling Sum and others (Jessop, 2004, 2010; Sum 2005, 2006; Jessop and Sum, 2001, 2010; Sum and Jessop, 2013; Van Heur, 2010) is a macro-theoretical framework inspired by Foucault, but retaining key insights of Marx, Gramsci and the regulation approach. CPE is a framework under construction combining conceptual perspectives from the regulation approach, materialist state theory and critical discourse analysis. It aims at 'making the cultural turn [within political economy] without falling into soft economic sociology' (Jessop and Oosterlynck, 2008) that is, integrating poststructuralist insights about the constructed and contingent nature of knowledge and discourse into an account of political economy that retains a materialist understanding of the specific contradictions and crisis tendencies of the capitalist mode of production. CPE, therefore, differentiates between semiotic (discursive) and structural (material) dimensions of social relations and puts the interplay between the two at the centre of analysis, aiming at both the interpretation of discourses and the explanation of causal mechanisms in the 'real world' (Fairclough, Jessop and Sayer, 2004: 24). The underlying ontology and epistemology of CPE 
is rooted in critical realism, as was the regulation approach before (Jessop, 2002). CPE, however, puts more emphasis on 'semiosis' defined as all forms of the social production of meaning. The discursive production of meaning is understood as historically contingent but not as free play of signs and symbols as more radical approaches to social constructivism would have it. Rather, it has to correspond to the material world in an 'organic' way in order not to appear as 'arbitrary, rationalistic and willed' (Jessop, 2010: 345); in other words, it must meaningfully relate to the 'decisive economic nucleus' (Gramsci, 1971) of social relations. Discourses are embedded and enacted within specific practices, projects and strategies of particular actors with particular interests, rather than being the disembodied circulation of differences without subjective agency.

$\mathrm{CPE}$ is here employed as a heuristics. Rather than fully operationalising the entire theoretical framework of CPE, key concepts are adopted that help make sense of the research object under investigation. Thus, from the rich oeuvre of CPE, the key concept here is 'economic imaginary', defined as follows: 'An economic imaginary is a semiotic order ... and, as such, constitutes the semiotic moment of a network of social practices in a given social field, institutional order, or wider social formation' (Jessop and Oosterlynck, 2008: 1157-1158).

Initially, economic imaginaries are primarily semiotic in nature but, depending on social balances of power and constellations of interests, may be gradually institutionalised, embodied and sedimented into more material forms. CPE differentiates the evolutionary moments of variation, selection and retention to analyse the development of economic imaginaries. In the moment of variation, economic imaginaries - in this case competing conceptions of decent work - are initially circulating relatively freely. Only some of these pass the moment of selection, which is based on strategic selectivities (Sum and Jessop, 2013: 214-219). Through the moment of retention, economic imaginaries may become hegemonic, discursively reinforced and eventually materially sedimented and institutionalised to consolidate new forms of social praxis. This process, however, is never fully complete. Economic imaginaries are rather 'only ever partially constituted. There are always interstitial, residual, marginal, irrelevant, recalcitrant and plain contradictory elements that escape any attempt to identify, govern, and stabilise a given economic arrangement or broader economic order' (Jessop, 2004: 163). The partiality and incompleteness of economic imaginaries also means that there is always space for contestation, appropriation or resistance as a fourth moment of the evolutionary process, however marginal, so that sub- or counter-hegemonic discourses may emerge from a variety of scales. These spaces for potential resistance or counter-hegemony depend partly on 'the gaps between discourses and practices' (Sum, 2006: 20).

When analysing the evolution of economic imaginaries, CPE looks at hegemonic, sub- and counter-hegemonic actors involved in their variation, selection and retention or contestation. NgaiLing Sum $(2005,2006)$ unravels the relationships among hegemony, sub- and counter-hegemony, referring to neo-liberalism as a hegemonic project. The hegemonic codes of neo-liberalism include discourses of competitiveness, privatisation, deregulation and free trade. Key actors ('organic intellectuals' in Gramsci's sense) promoting these codes are to be found within international organisations such as the IMF, the World Bank and the World Trade Organisation (WTO), as well as on the different levels of states and governments (national states, supra-national states such as the European Union, local governments). However, in line with Gramsci, hegemony needs to be secured within the (transnational) civil society, which is why non-state actors such as transnational corporations, think tanks, consultancy firms, rating agencies, NGOs, trade unions and so forth play a crucial role. So, hegemonic discourses emerge from a variety of local to global scales and from three 'mediating arenas': international organisations, states and civil society (Sum, 2006: 11). But from these scales and arenas, sub- and counter-hegemonic discourses may emerge as well. The ILO, for instance, due to its tripartite structure, while not in opposition to international competition and free trade per se, aims to strengthen the 'social dimension of globalization' (ILO, 2008) which extends 
the hegemonic meaning of globalisation but 'can be subsumed and contained within the hegemonic codes' (Sum, 2005), making the ILO a site for both hegemonic actors (powerful member states, employer organisations) and sub-hegemonic actors (other member states, trade unions). Subhegemonic discourses and practices 'may strengthen the overall consensus around the hegemonic project' (Sum, 2006: 21) when they become appropriated by hegemonic actors and absorbed into hegemonic discourses. Typical sub-hegemonic actors include service-oriented NGOs providing social services that, while in many cases motivated by humanistic ideals or similar non-market oriented imaginaries, effectively strengthen market rule by serving as 'flanking mechanisms' (Graefe, 2006) for the neo-liberalised market regime. Lastly, counter-hegemonic discourses and practices can be defined as those which contribute to the articulation of a counter-hegemonic project that cannot be subsumed and absorbed into the hegemonic project. Typical counter-hegemonic actors include a huge variety of social movements and movement-oriented NGOs, certain types of trade unions or echelons within them, critical intellectuals and producers of counter-culture. These actors operate within their respective local settings as well as on global and regional scales in arenas and networks such as the World and regional Social Forums.

\section{The Emergence of the Decent Work Discourse}

$\mathrm{CPE}$, as inspired by Foucault, looks at the historical moment in which a new discourse, such as decent work, emerges and traces its development back to what came before. This 'genealogical' method does not aim to determine the 'origin' of the decent work discourse, but rather to investigate what enabled its 'emergence' (McNay, 1994: 89). Embedding this genealogy into the CPE framework, with its links to regulation theory, means to look at the conditions of emergence in terms of the different periods of capitalist development, different regimes of accumulation and different modes of regulation. This section briefly outlines the historical development of global labour regulation and situates it within the history of capitalist development in general, thereby contextualising the emergence of decent work historically and theoretically.

\section{Fordism and the Periphery}

Fordism - the period of capitalist development from the end of World War II until the world economic crisis of the 1970s - rested on the successful articulation of mass production and mass consumption. The Fordist regime of accumulation was one of 'intensive accumulation with growing mass consumption' (Lipietz, 1988: 23); that is, accumulation rested on growth in productivity and corresponding growth in effective demand. The Fordist mode of regulation regulated the wage relation in such a way that the basic contradiction between wages as costs of production and wages as sources of demand was temporarily resolved by tying wage increases to growth in productivity. The Fordist wage relation represented an institutionalised compromise between capital and labour within national economies, forged by labour unions and business associations and mediated by the Keynesian welfare state, stabilising mass consumption and thus capital accumulation (Hirsch, 1995: 78).

The familiar account of Fordism as mass production plus mass consumption mediated by the welfare state carries a strong bias towards Western Europe and Northern America. Within countries of the Global South, Fordism showed a different face, because they were integrated into the 'international regime' (Boyer, 1990: 40) on unequal terms. Within the 'old [international] division of labour' (Lipietz, 1987: 47), the rich countries of the North primarily imported agricultural goods and raw materials from poor countries of the South to be used in industrial production for the domestic market. They were dependent on international exchange, but the dynamic of accumulation primarily 
rested on domestic demand bolstered by the welfare state. A smaller portion of finished goods was exported back to developing countries, which tried to emulate the Northern model by launching programmes of 'import substitution industrialisation' (Novy, Parnreiter and Fischer, 1999: 13). The emerging crisis of central Fordism, however, shifted the international division of labour as capital started to search for cheap labour in developing countries in the 1970s. The Fordist labour process was reorganised into a 'new, vertical division of labour between levels of skill inside branches of industry' (Lipietz, 1987: 71). Labour-intensive tasks defined as 'unskilled' were relocated to low-wage countries in the periphery as a major strategy to overcome the profitability crisis of Fordism, resulting in the emergence of 'global commodity chains' (Gereffi, 1994) and the replacement of import substitution with export orientation.

\section{Globalisation and Feminisation Of Labour}

Since the 1980s, the processes of internationalisation, liberalisation and deregulation have been discussed under the heading of neo-liberal globalisation. Globalisation is often understood as a process fuelled by technological and financial innovations. Although true in some sense, Silvia Federici points out that from a labour perspective another aspect is more important:

In my view, the technological and financial revolution that has accompanied the globalisation process and enabled it in some respects is less significant than the ability of capital to cut the cost of labour by massively expanding the world labour market (Federici, 2012: 52-53, my translation).

The crucial factors, according to her, are 'the increase in numbers of workers available for exploitation, the disciplining of these workers and the cut in labour costs' (Federici, 2012: 53, my translation). She identifies two major mechanisms by which the world population available for wage labour has been increased: continuous 'primitive accumulation' through a new round of global enclosures driving people off their customary lands and forests, depriving them of their means of subsistence and forcing them to look for wage labour on plantations or in the cities, and increased employment of women who have previously been excluded from the realm of wage labour (Federici, 2014: 94). . $^{3}$

The 'feminisation of labour' (Ruppert, 2001) is thus an integral part of globalisation, seen as the major strategy of capital to resolve the profitability crisis of Fordism. Usually, feminisation of labour is understood to grasp two different, though interrelated processes: the increase in female labour market participation and the proliferation of precarious, 'flexible' labour relations and insecure working conditions, previously seen as typically female, for both men and women (Standing, 1989, 1999). As import substitution came more and more to be seen as a failure, it was increasingly replaced by, or rather rearticulated with, the strategy of 'export-oriented industrialisation'(Gereffi, 1994: 100). In regulationist terms, the main logic of this accumulation strategy has been called 'primitive' or 'bloody Taylorization' (Lipietz, 1987: 74), referring to the relocation of labour-intensive industries such as garments, textiles and consumer electronics to countries or regions with very low wages, long working hours and bad conditions, especially in 'export processing zones' in countries of the Global South designed to attract foreign capital through legal incentives (tax breaks, exemptions from customs, restrictions of labour rights and so on). It is in these export-oriented industries that young women were especially targeted to recruit a cheap, seemingly docile and acquiescent labour force - an expectation these women were soon to prove wrong when they started to organise collectively for their interests (Salzinger, 2004).

Emerging global commodity chains came to be dominated by transnational corporations (TNCs). Export countries are competing over the most favourable conditions for foreign direct 
investment by TNCs. Since low wages and weak social (as well as environmental) standards are the only 'comparative advantage' of most countries of the Global South, competition between them resulted in the 'race to the bottom' (Ehmke, Simon and Simon, 2009: 26). In trying to attract foreign capital, labour markets were increasingly restructured according to the neo-liberal dogma of 'flexibility', thereby eroding labour standards and working conditions.

Transnational supply chains are highly complex. ${ }^{4}$ Hurley and Miller (2005) use the metaphor of an iceberg to depict the intricate web of contracting, subcontracting and sub-subcontracting in the global garment industry. The tip of the iceberg is the lead firm, in most cases a global retailer such as Walmart or a merchandiser of branded goods such as Nike and Adidas. They place orders with multinational manufacturers (Tier 1), themselves often large TNCs, which in turn subcontract parts of the production process to medium (Tier 2) and small manufacturers (Tier 3) to meet short turnaround times or the low prices dictated by the lead firm. Sub-subcontracting goes down to the level of home workers, the most precarious, informal and feminised segment of the supply chain. Above the waterline and thus visible is only the relationship between buyer and Tier 1 manufacturer (Hurley and Miller, 2005: 23). The subcontracting networks below the waterline are more invisible, making it hard for anyone to trace the production process and to monitor working conditions, but making it easy for TNCs to shift the responsibility for bad working conditions and labour rights abuses on to their subcontractors. Downward pressure on turnaround times and prices increases further down the supply chain, 'bringing associated problems of excessive overtime and subminimum wages' (Hurley and Miller, 2005: 26). Stephanie Barrientos' (2007: 244) 'gendered employment pyramid' further explains that beneath the level of paid home work there is an even larger background of unpaid domestic and care ('reproductive') work largely performed by women, upon which global production systems are built.

Globalisation has also restructured the 'care economy' (Chorus, 2013) in profound ways. Rising labour market participation of women in Northern countries has not led to a more equal redistribution of care work between women and men as many hoped for. Rather, 'social reproduction' continues to be seen as a women's task, despite their full integration into the 'productive' economy of capitalist wage labour. On the discursive level, gender regimes have been modernised to depict men and women as equals, one of the successes of the feminist movement. On the material level, however, gendered divisions of labour persist and continue to reproduce gender hierarchies. This contradictory process has been called the 'rhetorical modernisation' (Wetterer, 2003) of gender regimes. The practical solution to the reproduction problem in many cases has been the commodification of care work and its delegation to ethnically other women migrant women workers without or with limited citizenship rights acting as 'new maids' (Lutz, 2001) in middle-class households of rich countries. As a result, globalisation leads to the emergence of global 'care chains' (Lutz, 2005) as the hidden counterpart of global commodity chains.

\section{Global Labour Regulation}

As mentioned before, these processes of global restructuring have altered the terrain of global labour regulation in every respect. The Fordist development paradigm based on Keynesianism and national welfare statism has been replaced by the neo-liberal development paradigm based on supply-side economics and international competition statism (Hirsch, 2005: 145). It is in this context that the discourse on decent work has emerged. In the period immediately preceding the emergence of decent work, discussions about how to best prevent downward harmonisation of labour rights and social standards within transnational supply chains centred around the idea of a 'social clause' within the regime of the W'TO, linking labour standards to trade agreements and allowing for trade sanctions against states that would fail to comply with minimum standards. 
Whereas scholars, activists and unionists from the Global North have tended to stress the progressive potential of a multilateral social clause (Scherrer and Greven, 2001: 128), postcolonial and feminist scholars have argued that social clauses may actually be counterproductive with regard to protecting the most vulnerable workers at the bottom of transnational supply chains. Naila Kabeer (2004), for instance, argues that the enforcement of labour rights through trade sanctions may not only lead to declining employment in export industries but, more importantly, to the transfer of jobs from the formal to the informal economy, where women are concentrated and working conditions are far worse. The Western gaze tends to victimise 'Third World women' (Kabeer, 2004: 10) working in 'sweatshop' export factories, and neglect the positive aspects of formal factory work in comparison with available alternatives in the informal economy. Kabeer (2004: 4) maintains that women workers, trade unions and NGOs in the Global South have resisted the idea that social clauses will serve their interests, but other stakeholders have resisted the social clause proposal as well. First of all, neo-liberal economists and TNCs from around the globe have rejected it because it contradicts the ideology of free markets and free trade. Second, governments of developing countries have criticised it for basically serving protectionist interests of the North vis-àvis their low-cost competitors from the South (Kabeer, 2004: 8; Vosko, 2002: 22).

Given the widespread opposition against the social clause from a coalition of diverse actors, the attempt to implement a social clause within the WTO regime ultimately failed. As a result, the matter of global labour regulation was referred back to the ILO at a time when the organisation struggled to retain relevancy in the age of globalisation, as Standing (2008) argues. The impasse at the WTO 'fuelled the adoption of the ILO's [1998] Social Declaration, whose form resembles a social clause yet it is not attached to trade' (Vosko, 2002: 22, emphasis in the original). Instead of championing a binding regime of 'hard law' labour regulation linked to trade sanctions, the ILO moved away from the Fordist 'ratification model' (Elias, 2007: 51) and resorted to a neo-liberal model of 'soft law' labour regulation based on voluntariness and promotional measures. In line with the UN's Global Compact, the ILO began to embrace voluntary codes of conduct and CSR policies despite the fact that these have been widely criticised for failing to deliver on the promise of improving working conditions. The ILO tried to improve their effectiveness by promoting its core labour standards as the general frame of reference for minimum standards to be implemented in company codes.

This is the historical context out of which the decent work discourse emerged. The 1998 Declaration laid the groundwork by codifying the core labour standards that have been criticised for being compatible with the neo-liberal development paradigm (Elias, 2007; Standing, 2008) and for reinforcing hegemonic power relations within the ILO (Vosko, 2002). The Declaration on Social Justice for a Fair Globalization (ILO, 2008) further specified the decent work agenda. It was now defined as consisting of four pillars: employment creation, social protection, social dialogue and fundamental principles and rights at work. The ILO is a tripartite organisation and, as such, represents a specific configuration of relations of forces that become inscribed into its agenda. Decent work can be seen as a compromise or a

skilful effort at mediating escalating tensions inside the ILO between global capital, backed by a majority of industrialized states, and an increasingly vocal group of member states, trade unions, women's organizations and other NGOs concerned with improving the lives of marginalized workers (Vosko, 2002: 20).

It is thus not surprising that decent work is a discourse that is attractive to both workers and employers, because each have injected their own imaginary of what decent work should mean into the agenda. For employers and most states, the objective of employment creation allows for 
continuing with neo-liberal supply-side economics and policies of competitiveness. The notion of social dialogue replaces adversarial bargaining, as Standing (2008) notes, and thus works in the interest of global capital to minimise industrial action and labour unrest. Fundamental labour rights - as universal human rights rather than appendices of international trade agreements - and social protection, on the other hand, can be seen as concessions to trade unions and poor countries. The question is whether or not the decent work agenda has the potential to move beyond the neo-liberal development paradigm, or whether it serves to reinforce neo-liberal hegemony by accommodating criticisms of neo-liberalism discursively without providing the material means to actually change neo-liberal production processes.

\section{The Potentials and Limitations of Decent Work}

Kabeer (2004) is careful to argue that her scepticism of global labour standards in trade agreements - informed by postcolonial and feminist theory - is different from the neo-liberals' stance against regulation in that it is not founded on the belief in the self-regulating capacities of free markets. On the contrary, she argues that the 'struggle for labor standards needs to be broadened and made more inclusive by transforming itself into a struggle for a universal "social floor" (Kabeer, 2004: 28) in order for all workers to be able to struggle for better working conditions without being afraid of losing their jobs or having to enter into the informal labour market for new or alternative employment. Similarly, Barrientos (2007: 251) views decent work in general and social protection in particular as providing 'the basis for a more holistic approach to enhancing workers' rights in global production' vis-à-vis the narrow focus on social clauses and codes of conduct. The progressive potential of decent work is largely seen in the rhetorical inclusion of informal workers, especially women workers, and in the social protection pillar that - if put into material practice - would better cater to the needs of women who are forced to flexibly switch between paid home work for global production and unpaid housework for their families (Barrientos, 2007: 243). The ILO had long ignored the feminist discourse on social reproduction, but the decent work agenda seems to change this by addressing all forms of work, whether paid or unpaid, whether male or female, whether permanent or temporary - at least rhetorically.

The question, again, is whether this symbolic success of feminism in the discursive economy of representation translates into material improvements of actual working and living conditions. In $\mathrm{CPE}$ terms, does the feminist decent work imaginary have the potential to become counterhegemonic vis-à-vis neo-liberalism, or does it remain sub-hegemonic in that it 'can be subsumed and contained within the hegemonic codes' (Sum, 2005) of neo-liberalism? Answering this question would require careful empirical analyses of concrete cases in terms of how decent work imaginaries materialise to constitute new forms of labour praxis in particular contexts. This goes beyond the scope of this article. Some preliminary remarks on possible sites for future research on decent work may however be appropriate.

Next, two ILO initiatives will be explored, each of which is underpinned by either the feminist or the business case imaginary, in terms of the ways they may challenge or reinforce neo-liberal hegemony - the Domestic Workers Convention and the Better Work Programme.

\section{Decent Work for Domestic Workers}

Female migrant domestic workers are among the most marginalised, informal and precarious workers in the global economy. In many countries, they are not only explicitly excluded from national labour law; they also suffer from low wages and long working hours and do not enjoy any form of social protection (Schwenken, 2012). Although horror stories about slave-like conditions in 
countries such as Saudi Arabia abound, their struggle for decent work shows that these women are not faceless victims of globalisation, but workers who organise collectively to fight for their rights. Three years of intense campaigning by organised domestic workers have resulted in the adoption of the ILO's (2011) Convention Concerning Decent Work for Domestic Workers in 2011, entering force in 2013.

Helen Schwenken (2012) argues that the Domestic Workers Convention is a major step forward in terms of recognising the rights of domestic workers as workers and making visible their hidden labour. The intense campaign preceding the adoption of the convention was unique in that it was carried out by domestic workers' organisations themselves in coalition with trade union federations. Successful cooperation of formal trade unions and more informal organisations and networks in this case is a practical example for the progressive potential of decent work as suggested by Vosko (2002). The decent work agenda clearly enabled domestic workers to fight for the recognition of their rights as workers and the convention extends existing labour rights to this previously excluded group of informal workers. The feminist decent work imaginary here passed the moment of variation and became selected within the standard-setting procedure of the ILO. Within the discursive economy of representation, domestic workers now enjoy the same rights as other workers. However, the question remains whether this feminist victory on legal territory translates into new forms of material practices on the ground. In other words, does the imaginary have enough powerful backing to become further materialised or institutionalised in the 'actually existing economy' (Sum and Jessop, 2013: 166) of global care chains?

Schwenken (2012) is cautiously optimistic about the convention and sees its progressive potential largely in the ways it has enabled discussions about the informal economy, labour migration and gender relations within the ILO - topics that have long been ignored but that become more and more important under globalisation. She is, however, less optimistic about the convention's power to substantially challenge the structural conditions governing the field of transnational domestic work, that is, neo-liberal gender, migration and labour regimes. The instrument of an ILO convention is largely semiotic in nature and does not in and of itself have the power to challenge the neo-liberal development paradigm. The conditions for domestic workers to organise and fight for concrete improvements on the ground are nevertheless improved. If and how domestic workers will be able to make use of these new opportunities is an empirical question that depends on local balances of power and conjunctures of social struggles in particular contexts.

\section{The Better Work Programme}

The global Better Work Programme is a typical example of the kinds of initiatives the ILO is carrying out in the area of CSR under the umbrella of decent work. It was initiated in Cambodia as the Better Factories Programme as an attempt to help the Cambodian garment industry to secure orders following the phase-out of the Multi-Fibre Agreement in 2005. After the Cambodian experience had been reported as a success story benefitting both employers and workers (Ferenschild, 2011), Better Work was exported to other countries such as Indonesia, Vietnam, Lesotho, Jordan, Haiti and Nicaragua. Better Work is a partnership of the ILO and the International Finance Corporation (IFC) and, as such, an example of the new approach of the ILO to seek 'soft money from international agencies' (Standing, 2008: 381) to make up for decreased regular budget funding. The problem with this soft money is that the ILO becomes dependent on external donors and its programmes become donor-driven. The IFC is part of the World Bank Group and has the mandate to promote private-sector development in developing countries. It is not known for its stance against the neo-liberal development paradigm or its concern for marginalised workers. The joint venture of the ILO and the IFC, therefore, further exacerbates the contradictions within the 
decent work discourse. Better Work makes the 'business case' for decent work while maintaining that workers will benefit simultaneously.

Better Work aims to improve both company compliance with core labour standards and industry competitiveness in transnational supply chains, focusing on the global garment and textile industry. It offers technical services to both global buyers and local suppliers of garments and textiles in terms of quality assurance, monitoring and evaluation, as well as impact assessment. The idea is a classic win-win situation: Participation in Better Work would give the garment companies a competitive advantage in the global market because CSR management, auditing and certification are now integral parts of transnational supply chains. The workers, of course, would benefit from better working conditions through improved company compliance. Benefits for garment factories in the Global South are primarily seen in helping them to secure contract relationships with international buyers such as major sports brands like Nike and Adidas. The demands by these buyers to comply with their respective codes of conduct or CSR policy are thus the main motivation for the suppliers to participate in Better Work. It is the first major monitoring project of the ILO and, as such, replaces private auditing and monitoring schemes in participating factories. It thus serves to reduce auditing costs for employers while improving the credibility of their codes of conduct and CSR mechanisms.

The track record of Better Work from a worker's perspective is ambiguous. On the one hand, some improvements of the working conditions in participating factories have been recorded (Ferenschild, 2011; Merk, 2012), especially in the area of occupational safety and health. On the other hand, Better Work adopts a very technical understanding of labour rights and social standards that obscures some important political problems with decent work. For example, assessing wages only against the legal minimum wage is not sufficient to measure decent work as the minimum wage in many countries is still below subsistence level. Here, the limitation of the decent work agenda of not including 'the right to earn a living wage - something that was included in Article 23 of the Universal Declaration of Human Rights' (Elias, 2007: 52) - is an obvious problem. The ILO has shied away from addressing the living wage issue, presumably because it is very controversial and likely to undermine the harmonious notion of 'social dialogue' if it was pursued. Companies can only afford to pay wages below subsistence level because they can rely on unpaid domestic, care and subsistence work, mostly performed by women. The lower the wage in the factory, the stronger is the compulsion to work extra hours on rice paddies, as street vendors and in kitchens. As long as decent work in general and Better Work in particular does not address this issue head-on, the positive effects for women's double shifts are likely to be limited. This lends credibility to Standing's pessimistic view.

If the optimistic view is right with respect to informal and marginalised workers, decent work must effectively contribute to extending labour rights down the supply chains through to the level of home work. Better Work, unsurprisingly, only addresses Tier 1 factories with direct contract relationships to transnational buyers; that is, it replicates the limitations of other instruments of global labour regulation in that it does not have the capacity to effect change in actual labour practices further down the supply chain (Ferenschild, 2011). Home workers remain below the waterline and thus invisible to the Better Work Programme. Subcontracted factories and factories that do not produce for export are not covered (Merk, 2012: 19).

Therefore, while Better Work helps buyers and suppliers in very material ways with monitoring their CSR strategies as part of transnational supply chain management, the discursive recognition of workers' rights does not translate easily into actual improvements on the ground. In CPE terms, while both the feminist and the business case imaginary of decent work are present on the semiotic level (variation), the business case imaginary is more powerful and thus more likely to become selected and retained in material practices. The driving force behind Better Work is not so 
much realising labour rights as human rights or fulfilling workers' demands for better working conditions as it is the growing demand for social auditing and certification schemes within transnational supply chains and the trend towards 'ethical capitalism' (Barry, 2004) more broadly.

\section{Conclusion}

Decent work emerged in the context of neo-liberal globalisation, which itself marks the transition from Fordism to neo-liberalism. The societal problem arising in this context that decent work responds to is two-fold. On the one hand, decent work responds to the problem of indecent working conditions, poverty wages and social insecurity. Globalisation has led to increasingly informal and precarious employment, and decent work is ostensibly designed to rectify this problem by introducing new labour policies. This discourse strand can be found in hegemonic sites (mainly the ILO and associated governments and business associations) as well as some sub-hegemonic sites (e.g. service-oriented NGOs and business unions). On the other hand, decent work responds to a problem of legitimation in the current conjuncture of global capitalism. Social movements have contributed to a crisis of legitimacy by challenging the hegemony of neo-liberal globalisation, criticising TNCs for sweatshop conditions in their factories and raising public awareness about labour and human rights violations. Decent work responds to this legitimation problem by symbolically proclaiming the right to decent work for all without challenging the structural mechanisms causing indecent working conditions in the first place. This discourse strand is mainly to be found in counter-hegemonic sites (e.g. movement-oriented NGOs and social movement unions). Some sub-hegemonic actors may also occupy a third space in between the two general lines and navigate between acknowledging the legitimatising function of decent work and seizing the opportunities for incremental change arising therefrom (e.g. development NGOs and social democratic unions).

We can thus conclude that the decent work discourse is a contradictory ensemble of competing economic imaginaries. The feminist decent work imaginary as exemplified by the Domestic Workers Convention, on the one hand, challenges neo-liberal codes by discursively extending labour rights to new groups of marginalised and informal, mostly female workers. On the other hand, its material power to substantially challenge the social structures of neo-liberal production, giving rise to informalisation, casualisation and marginalisation in the first place, is limited. Thus, the feminist imaginary may be conceptualised as counter-hegemonic vis-à-vis neoliberalism on the discursive level. Taking into account Sum's differentiation of sub- and counterhegemony, however, it may also be conceptualised as a sub-hegemonic discourse that extends the meaning of notions such as 'labour' or 'worker' to formerly excluded parts of the working population, recognises their labour rights - at least discursively - but fails to provide the material basis for effectively moving beyond the neo-liberal development paradigm. Whether it serves as a 'flanking mechanism' (Graefe, 2006) for neo-liberalism or whether it becomes further appropriated by progressive actors to challenge neo-liberal practices materially, remains to be seen.

The business case decent work imaginary as exemplified by the Better Work Programme reinforces the hegemonic codes of neo-liberalism by espousing competitiveness and voluntary CSR as part of transnational supply chain management. It represents a minimum standard approach to decent work that primarily serves to 're-ethicalise' neo-liberal production, that is, to fulfil global capital's need for cheap but ethical labour. This need is now a general feature of the current 'latest round of roll-out neo-liberalism' (Sum, 2010) as a result of anti-sweatshop campaigns and public criticism staged by labour unions and social movements. Decent work, here, can be conceptualised as part of Sum's (2010) 'new ethicalism' reconnecting neo-liberal production practices to moral 
values without substantially challenging underlying power relations, thus reinforcing neo-liberal hegemony by co-opting criticism rather than transcending neo-liberalism. New ethicalism is a 'technology of control in which the audit and certification discourses, practices and procedures are used to ward off dangers and gain mastery over social activism' (Sum, 2010: 65). This corresponds to Franco Barchiesi's (2012: 135) argument about decent work as 'an antidote to radical demands' holding in a 'material reality where work is a condition of dignity and decency for a shrinking minority of the population'. Depending on the specific actors and their projects making use of decent work in different contexts, decent work imaginaries may thus be both sub-hegemonic in helping neo-liberalism to adapt and reproduce its hegemony and counter-hegemonic in supporting marginalised workers to combat marginalisation and reclaim dignity. If the latter shall be referred to unequivocally, perhaps the notion of 'dignified labour' is a better term. ${ }^{5}$

In CPE terms, economic imaginaries are understood as addressing or processing fundamental contradictions based in the social forms of capitalism. Looking at decent work in these terms also means asking about the contradictions it addresses and the ways in which these are contained within the imaginary, albeit necessarily partially and temporarily. Therefore, it also means being attentive to how these contradictions may escape containment and resurface as conflicts and crises. Obviously, this entails reflecting on the basic contradiction between capital and labour, how it is being regulated in the wage relation, how decent work imaginaries are addressing it and how recurring labour conflicts continually demonstrate that this fundamental contradiction of capitalism cannot easily be contained. After all, the right to decent work appears as that 'which we cannot not want' (Brown, 2000: 231) - we cannot not want poor working conditions to be improved, no matter how slow and incremental. However, we must also ask whether such improvements empower workers to collectively organise for their interests and actively fight for further societal change or whether they may serve as a 'passive revolution' (Gramsci, 1971) to flank neo-liberalism and pre-empt, disempower or displace more radical, counter-hegemonic imaginaries and practices.

\section{NOTES}

1. I would like to thank the editors of this Special Issue - Phoebe Moore, Charles Dannreuther and Christian Möllmann - as well as two anonymous reviewers for their useful comments on earlier drafts of this article. I am also grateful to Uta Ruppert, Claes Belfrage, Melanie Schreiber and Daniel Keil for their help. The usual disclaimers apply.

2. The notion of 'economic imaginaries' will be explained in the section on CPE.

3. An example from Indonesia for the first mechanism is the palm oil industry. Primary forests are slashed and burned to make way for palm oil plantations; indigenous people are driven off their land and turned into day labourers working on the plantations (Humanity United, n.d.). Although this is an important aspect of the making of the Indonesian working class, I here focus on the second mechanism involving the feminisation of labour.

4. The concept of 'transnational supply chains' (Hurley and Miller, 2005) builds on Gerreffi's (1994) 'global commodity chains' but explicitly incorporates the informalised and feminised segment of home work at the bottom end of the apparel supply chain.

5. A Thai cooperative producing clothing in a factory under workers' control that is a member of the transnational No Chains network calls itself Dignity Returns and promotes its products as 'Sweat-Free Products of Dignified Labor' (http://www.dignityreturns.org). The notion of 'dignified labour' here represents a counter-hegemonic alternative to 'decent work'. 


\section{REFERENCES}

Barchiesi, F. (2012) 'Imagining the patriotic worker: The idea of "decent work" in the ANC's political discourse', in Lissoni, A. et al. (eds) One Hundred Years of the ANC: Debating Liberation Histories Today. Johannesburg: Wits University Press.

Barrientos, S. (2007) 'Gender, codes of conduct, and labor standards in global production systems', in Van Staveren, I., Elson, D. and Cagatay, N. (eds.) The feminist economic of trade. London: Routledge.

Barry, A. (2004) 'Ethical capitalism', in Larner, W. and Walters, W. (eds.) Global governmentality: Governing international spaces, London: Routledge.

Boyer, R. (1990) The regulation school: A critical introduction. New York: Columbia University Press.

Brown, W. (2000) 'Suffering rights as paradoxes', Constellations, 7(2): 230-241.

Chorus, S. (2013) Care-Ökonomie im Postfordismus: Perspektiven einer integralen Ökonomie-Theorie. Münster: Westfälisches Dampfboot.

Chowdhry, G. (2004) 'Postcolonial interrogations of child labour: Human rights, carpet trade, and Rugmark in India', in Chowdhry, G. and Nair, S. (eds.) Power, postcolonialism and international relations: Reading race, gender and class. London: Routledge.

Cox, R. (1977) 'Labor and hegemony', International Organization, 31(1): 385-424.

Ehmke, E., Simon, A. and Simon, J. (2009) 'Internationale Arbeitsstandards im globalen Kapitalismus', in Ehmke, E., Fichter, M., Simon, N. and Zeuner, B. (eds.) Internationale Arbeitsstandards in einer globalisierten Welt. Wiesbaden: VS.

Elias, J. (2007) 'Women workers and labour standards: The problem of "human rights", Review of International Studies, 33(1): 45-57.

Fairclough, N., Jessop, B. and Sayer, A. (2004) 'Critical realism and semiosis', in Joseph, J. and Roberts, J.M. (eds.) Realism, discourse and deconstruction. London: Routledge.

Federici, S. (2012) Aufstand aus der Küche: Reproduktionsarbeit im globalen Kapitalismus und die unvollendete feministische Revolution. Münster: edition assemblage.

Federici, S. (2014) 'The reproduction of labour power in the global economy and the unfinished feminist revolution', in Atzeni, M. (ed.) Workers and labour in a globalised capitalism: Contemporary themes and theoretical issues. Basingstoke: Palgrave Macmillan.

Ferenschild, S. (2011) "Better Factories Program" in Kambodscha - ist der Name auch Programm?', in Burckhardt, G. (ed.) Mythos CSR: Unternebmensverantwortung und Regulierungslücken. Bonn: Horlemann.

Gereffi, G. (1994) 'The organization of buyer-driven global commodity chains: How U.S. retailers shape overseas production networks', in Gereffi, G. and Korzeniewicz, M. (eds.) Commodity chains and global capitalism. Westport: Praeger.

Graefe, P. (2006) 'Social economy policies as flanking for neoliberalism: Transnational policy solutions, emergent contradictions, local alternatives', Policy and Society, 25(3): 69-86.

Gramsci, A. (1971) Selections from the Prison Notebooks. New York: International Publishers. 
Hirsch, J. (1995) Der nationale Wettbewerbsstaat: Staat, Demokratie und Politik im globalen Kapitalismus. Berlin: Edition ID-Archiv.

Hirsch, J. (2005) Materialistische Staatstheorie: Transformationsprozesse des kapitalistischen Staatensystems. Hamburg: VSA.

Humanity United (n.d.) Exploitative labor practices in the global palm oil industry, Prepared by Accenture for Humanity United. Available online at http://humanityunited.org/pdfs/ Modern_Slavery_in_the_Palm_Oil_Industry.pdf [Accessed: 23 May 2014].

Hurley, J. and Miller, D. (2005) 'The changing face of the global garment industry', in Hale, A. and Wills, J. (eds.) Threads of labour: Garment industry supply chains from the workers' perspective. Malden: Blackwell.

International Labour Organisation (ILO) (1996) ILO convention concerning home work, No. 177. Geneva: International Labour Office.

International Labour Organisation (ILO) (1998) ILO declaration on fundamental principles and rights at work and its follow-up. Geneva: International Labour Office.

International Labour Organisation (ILO) (2008) ILO declaration on social justice for a fair globalization. Geneva: International Labour Office.

International Labour Organisation (ILO) (2011) ILO convention concerning decent work for domestic workers, No. 189. Geneva: International Labour Office.

Jessop, B. (2002) 'Capitalism, the regulation approach, and critical realism', in Brown, A., Fleetwood, S. and Roberts, J. (eds.) Critical realism and Marxism. London: Routledge.

Jessop, B. (2004) 'Critical semiotic analysis and cultural political economy', Critical Discourse Studies, 1(2): 159-174.

Jessop, B. (2010) 'Cultural political economy and critical policy studies', Critical Policy Studies, 3(3-4): 336-356.

Jessop, B. and Oosterlynck, S. (2008) 'Cultural political economy: On making the cultural turn without falling into soft economic sociology', Geoforum, 39: 1155-1169.

Jessop, B. and Sum, N.-L. (2001) 'Pre-disciplinary and post-disciplinary perspectives', New Political Economy, 6(1): 89-101.

Jessop, B. and Sum, N.-L. (2010) 'Cultural political economy: Logics of discovery, epistemic fallacies, the complexity of emergence, and the potential of the cultural turn', New Political Economy, 15(3): 445-451.

Kabeer, N. (2004) 'Globalization, labor standards, and women's rights: Dilemmas of collective (in)action in an interdependent world', Feminist Economics, 10(1): 3-35.

Lipietz, A. (1987) Mirages and miracles: The crisis of global Fordism. London: Verso.

Lipietz, A. (1988) 'Accumulation, crises, and ways out: Some methodological reflections on the concept of "regulation", International Journal of Political Economy, 18(2): 10-43.

Lutz, H. (2001) 'Die neue Dienstmädchenfrage im Zeitalter der Globalisierung', in Fechter, M. (ed.) Gesellschaftliche Perspektiven - Wissenschaft - Globalisierung: Jahrbuch der Hessischen Gesellschaft für Demokratie und Ökologie. Essen: Klartext. 
Lutz, H. (2005) 'Der Privathaushalt als Weltmarkt für weibliche Arbeitskräfte', Peripherie, 97/98: 6587.

McNay, L. (1994) Foucault: A critical introduction. Cambridge: Polity Press.

Merk, J. (2012) 10 years of the better factories Cambodia project: A critical evaluation. Amsterdam: Clean Clothes Campaign and Community Legal Education Centre.

Novy, A., Parnreiter, C. and Fischer, K. (1999) 'Globalisierung und Peripherie', in idem (eds.) Globalisierung und Peripherie: Umstrukturierung in Lateinamerika, Afrika und Asien. Frankfurt: Brandes \& Apsel.

Pfau-Effinger, B. (2004) 'Socio-historical paths of the male breadwinner model: An explanation of cross-national differences', The British Journal of Sociology, 55(3): 377-399.

Prugl, E. (1999) The global construction of gender: home-based work in the political economy of the $20^{\text {th }}$ century. New York: Columbia University Press.

Ruppert, U. (2001) 'Geschlechterverhältnisse in der Globalisierung', in Stiftung Entwicklung und Frieden (ed.) Globale Trends 2002: Fakten, Analysen, Prognosen. Frankfurt: Fischer.

Salzinger, L. (2004) 'From gender as object to gender as verb: Rethinking how global restructuring happens', Critical Sociology, 30(1): 43-62.

Scherrer, C. and Greven, T. (2001) Global rules for trade: Codes of conduct, social labeling, workers' rights clauses. Münster: Westfälisches Dampfboot.

Schwenken, H. (2012) Vom "Dienstmädchen" zur "ArbeiterIn": Die Konvention Nr. 189 der Internationalen Arbeitsorganisation "Menschenwürdige Arbeit für Hausangestellte", in Jung, A. and Hauf, F. (eds.) Gute Arbeit weltweit? Entwicklungspolitik, Gewerkschaften und Wissenschaft zu globalen Arbeitsrechten und Sozialstandards. Frankfurt: EPN Hessen.

Sengenberger, W. (2001) 'Decent work: The International Labour Organization agenda', Dialogue and Cooperation, 2: 39-54.

Standing, G. (1989) 'Global feminization through flexible labour', World Development, 17(7): 10771098.

Standing, G. (1999) 'Global feminization through flexible labour: A theme revisited', World Development, 27(3): 583-602.

Standing, G. (2008) 'The ILO: An agency for globalization?', Development and Change, 39 (3): 355-384.

Sum, N.-L. (2005) From "integral state" to "integral world economic order": Towards a neo-Gramscian cultural international political economy. Cultural Political Economy Working Paper No. 7. Lancaster: CPERC.

Sum, N.-L. (2006) 'Towards a cultural political economy: Discourses, material power and (counter)hegemony', Demologos Spot Paper. Lancaster: CPERC.

Sum, N.-L. (2010) 'Wal-Martization and CSR-ization in developing countries', in Utting, P. and Marques, J.C. (eds.) Corporate social responsibility and regulatory governance. Basingstoke: Palgrave.

Sum, N.-L. and Jessop, B. (2013) Towards a cultural political economy: Putting culture in its place in political economy. Cheltenham: Edward Elgar.

Van Heur, B. (2010) 'Beyond regulation: Towards a cultural political economy of complexity and emergence', New Political Economy, 15(3): 421-444. 
Vosko, L. (2002) "Decent work": The shifting role of the ILO and the struggle for global social justice', Global Social Policy, 2(1): 19-46.

Wetterer, A. (2003) 'Rhetorische Modernisierung: Das Verschwinden der Ungleichheit aus dem zeitgenössischen Differenzwissen', in Knapp, G.-A. and Wetterer, A. (eds.) Achsen der Differenæ: Gesellschaftstheorie und feministische Kritik II. Münster: Westfälisches Dampfboot.

\section{BIOGRAPHICAL NOTE}

FELIX HAUF is a research associate and $\mathrm{PhD}$ candidate at the Department of Political Science at Goethe University Frankfurt. He studied political science, economics, sociology and philosophy at Goethe University Frankfurt and York University, Toronto. His PhD project on the Cultural Political Economy of labour struggles in Indonesia is soon to be completed. His research interests include International and Feminist Political Economy, Cultural Political Economy and Critical Grounded Theory as well as labour unions and social movements, especially in Indonesia. [Email: hauf@soz.uni-frankfurt.de] 